\title{
UPDATED GUIDELINES FOR THE USE OF RIFAMYCINS FOR THE TREATMENT OF TUBERCULOSIS IN HIV-INFECTED PATIENTS TAKING PROTEASE INHIBITORS OR NON-NUCLEOSIDE REVERSE TRANSCRIPTASE INHIBITORS
}

\author{
Centers for Disease Control and Prevention \\ National Center for HIV, STD and TB Prevention \\ Division of Tuberculosis Elimination
}

Two previously published reports provided guidelines for managing the pharmacological interactions that can result when patients are treated with protease inhibitors (PIs) or non-nucleoside reverse transcriptase inhibitors (NNRTIs) for human immunodeficiency virus (HIV) infection together with rifamycins for tuberculosis (TB).1,2 This article presents current data pertaining to interactions between these agents, with recommendations for their use from a group of Centers for Disease Control (CDC) scientists and outside expert consultants; these include initial recommendations for the PIs lopinavir/ritonavir, atazanavir, and fosamprenavir (a phosphate ester prodrug of amprenavir).

\section{MECHANISMS OF RIFAMYCINS-ANTIRETROVIRAL} DRUG INTERACTIONS

The principal locus of these drug-drug interactions is the cytochrome P450 (CYP) system in the intestinal wall and liver, specifically the iso-enzyme CYP3A4. ${ }^{3}$ Rifamycins are antituberculosis agents that induce the activity of CYP3A4 and may thereby substantially decrease serum concentrations of PIs and NNRTIs. The available rifamycins differ in potency as CYP3A4 inducers, with rifampin (rifampicin) being the most potent, rifapentine being intermediate, and rifabutin being the least potent inducer. ${ }^{4}$ As such, rifabutin can be safely used with most PIs and NNRTIs, except saquinavir and delavirdine (see Table II). Unlike rifampin (rifampicin) and rifapentine, however, rifabutin is also a substrate for CYP3A4; its serum concentration is therefore affected by the degree to which CYP3A4 is inhibited or induced by PIs and NNRTIs. Rifapentine, a long-acting rifamycin, is not recommended for the treatment of TB in HIV-infected persons because of its association with acquired rifamycin resistance in such patients.

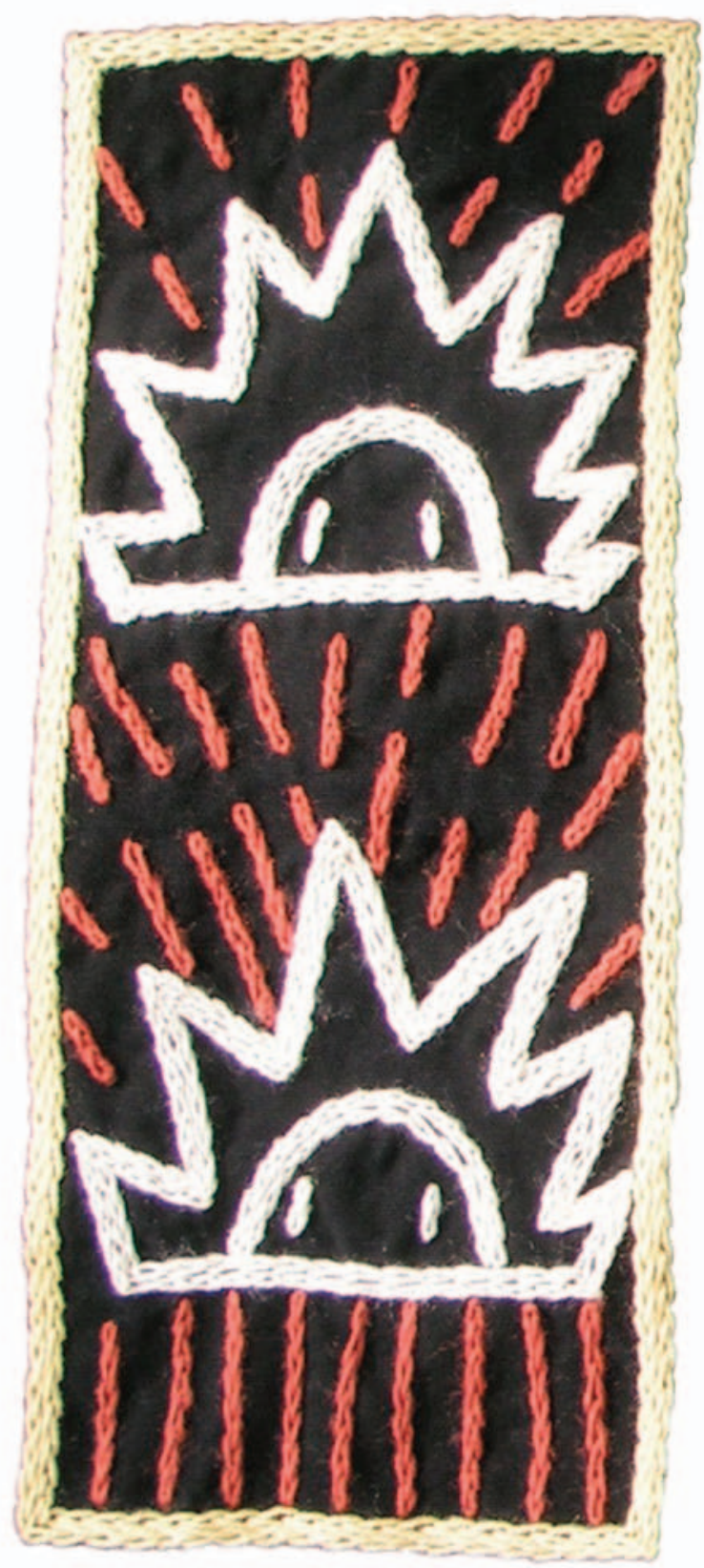


Among the available antiretroviral (ARV) agents, ritonavir has the highest potency in inhibiting CYP3A4, a quality that increases the serum concentrations of other coadministered $\mathrm{PIs}_{1}{ }^{6}$ although it can also increase concentrations of rifabutin and a rifabutin metabolite to toxic levels.

\section{RIFAMPIN (RIFAMPICIN) AND ANTIRETROVIRAL} THERAPY (TABLE I)

Initial guidance from the CDC stated that use of rifampin (rifampicin) was contraindicated for persons taking NNRTIs and PIs.' Subsequent data, however, have supported the use of rifampin (rifampicin) with certain combinations of ARV agents. These include:

- ritonavir with nucleoside/tide reverse transcriptase inhibitors (NRTIs) ${ }^{8}$

efavirenz with NRTIs. ${ }^{9-11}$

Alternative, less supported, ARV combinations for use with rifampin (rifampicin) include:

- ritonavir (400 mg twice daily) and saquinavir (400 mg twice daily) with NRTIs ${ }^{12}$

- ritonavir (400 mg twice daily) and lopinavir (400 mg twice daily) with NRTIs (when the current co- formulated lopinavir/ritonavir combination is supplemented with additional ritonavir, see Table I) ${ }^{13}$

nevirapine with NRTIs ${ }^{14-17}$ (and Boehringer Ingelheim, Viramune Product information, 2002)

triple NRTIs. ${ }^{1,2}$

It is noteworthy that the ritonavir dose typically used for pharmaco-enhancement of co-administered PIs (i.e. 100 mg or 200 mg twice daily), ${ }_{1}^{19}$ though less likely to produce adverse events than higher doses, still results in net CYP3A4 induction when used with rifampin (rifampicin) ${ }^{13}$ (and BMS Virology, Reyataz package insert, 2003). Data are lacking for other PIs co-administered with rifampin (rifampicin) and ritonavir $400 \mathrm{mg}$ twice daily. The use of nevirapine and NRTIs with rifampin (rifampicin) is of particular importance in countries with limited resources where rifabutin may not be available, and for pregnant patients, in whom efavirenz cannot be used. Despite pharmacokinetic data showing a significant reduction in nevirapine concentrations when co-administered with rifampin (rifampicin), ${ }_{1}^{14-17}$ two small studies demonstrated a favourable clinical and virological response. ${ }^{16,18}$ Nonetheless, until additional data are available, rifampin (rifampicin)- and nevirapine-containing ARV regimens 
TABLE I. RECOMMENDATIONS FOR CO-ADMINISTERING PROTEASE INHIBITORS AND NON-NUCLEOSIDE REVERSE TRANSCRIPTASE INHIBITORS WITH RIFAMPIN (RIFAMPICIN) - UNITED STATES, 2004*

\begin{tabular}{|c|c|c|}
\hline Single Pls & $\begin{array}{l}\text { Antiretroviral } \\
\text { dose change }\end{array}$ & $\begin{array}{l}\text { Rifampin (rifampicin) } \\
\text { dose change* }\end{array}$ \\
\hline Ritonavir & None & $\begin{array}{l}\text { None } \\
(600 \mathrm{mg} / \mathrm{d})\end{array}$ \\
\hline Amprenavir & \multicolumn{2}{|c|}{$\begin{array}{l}\text { Rifampin (rifampicin) and amprenavir should } \\
\text { not be used together }\end{array}$} \\
\hline fos-amprenavir & \multicolumn{2}{|c|}{$\begin{array}{l}\text { Rifampin (rifampicin) and fos-amprenavir } \\
\text { should not be used together }\end{array}$} \\
\hline Atazanavir & \multicolumn{2}{|c|}{$\begin{array}{l}\text { Rifampin (rifampicin) and atazanavir should } \\
\text { not be used together }\end{array}$} \\
\hline Indinavir & \multicolumn{2}{|c|}{$\begin{array}{l}\text { Rifampin (rifampicin) and indinavir should } \\
\text { not be used together }\end{array}$} \\
\hline Nelfinavir & \multicolumn{2}{|c|}{$\begin{array}{l}\text { Rifampin (rifampicin) and nelfinavir should } \\
\text { not be used together }\end{array}$} \\
\hline Saquinavir & \multicolumn{2}{|c|}{$\begin{array}{l}\text { Rifampin (rifampicin) and saquinavir should } \\
\text { not be used together }\end{array}$} \\
\hline Dual PI combinations & $\begin{array}{l}\text { Recommended change } \\
\text { in dose of } \\
\text { antiretroviral drug }\end{array}$ & $\begin{array}{l}\text { Recommended change } \\
\text { in dose of rifampin } \\
\text { (rifampicin) }\end{array}$ \\
\hline Saquinavir / ritonavir & $\begin{array}{l}\text { Saquinavir } 400 \mathrm{mg}+ \\
\text { ritonavir } 400 \mathrm{mg} \\
\text { twice/day }\end{array}$ & $\begin{array}{l}\text { None } \\
(600 \mathrm{mg} / \text { day })\end{array}$ \\
\hline $\begin{array}{l}\text { Phamaco-augmented lopinavir/ritonavir } \\
\left.\text { (Kaletra }{ }^{\circledR}\right) \\
\text { Note: Additional ritonavir required }\end{array}$ & $\begin{array}{l}\text { Lopinavir/ritonavir } \\
\left(\text { Kaletra }{ }^{\circledR}\right)-3 \text { capsules } \\
+300 \mathrm{mg} \text { ritonavir } \\
\text { twice/day }\end{array}$ & $\begin{array}{l}\text { None } \\
(600 \mathrm{mg} / \text { day })\end{array}$ \\
\hline Lopinavir/ritonavir (Kaletra ${ }^{\circledR}$ ) & \multicolumn{2}{|c|}{$\begin{array}{l}\text { Rifampin (rifampicin) and lopinavir/ritonavir } \\
\text { (Kaletra }{ }^{\circledR} \text { ) should not be used together. If } \\
\text { Kaletra is used with rifampin (rifampicin), } \\
\text { additional ritonavir is required (see above) }\end{array}$} \\
\hline
\end{tabular}

\section{Comments}

Ritonavir AUC $\downarrow$ by $35 \%$; no change in rifampin (rifampicin) concentration Amprenavir AUC $\downarrow$ by $82 \%$, Cmin $\downarrow$ by $92 \%$

See amprenavir

Interaction studies not performed, but marked decrease in atazanavir concentrations predicted Indinavir AUC $\downarrow$ 89\%

Nelfinavir AUC $\downarrow 82 \%$

Saquinavir AUC $\downarrow 84 \%$

\section{Comments}

Limited clinical experience ${ }^{12}$

Limited clinical experience. Increased hepatotoxicity from ritonavir is likely ${ }^{13}$

Lopinavir AUC $\downarrow$ by $75 \%$ \& Cmin $\downarrow$ by $99 \%$

\section{Comments}

Efavirenz AUC $\downarrow$ by $22 \%$; no change in rifampin (rifampicin) concentration

Nevirapine AUC $\downarrow 37 \%$ - 58\% and Cmin $\downarrow$ 68\% with $200 \mathrm{mg} 2 x /$ day dose $^{14-16}$ (and Boehringer Ingelheim Viramune product information). Limited, though favorable data for efficacy of $200 \mathrm{mg}$ BID dose, although should only be used if no other options exist and clinical and virological monitoring possible. ${ }^{16,17}$ May consider $300 \mathrm{mg}$ BID only if close biochemical monitoring feasible; however, no clinical, pharmacokinetic, or safety data available for 300 mg BID dose

Delavirdine AUC $\downarrow$ by $95 \%$
Delavirdine

Rifampin (rifampicin) and delavirdine should not be used together

\section{$(600 \mathrm{mg} / \mathrm{day})$ \\ None} ( $600 \mathrm{mg} /$ day)

*References proved for combinations with either inconclusive or limited data. tMay $\downarrow$ to $600 \mathrm{mg} /$ day if $800 \mathrm{mg}$ dose not easily tolerated. should only be used when no other options are available and close clinical and virological monitoring can be performed.

\section{RIFABUTIN AND ANTIRETROVIRAL THERAPY (TABLE II)}

Rifabutin can be used with most Pls, including atazanavir and fos-amprenavir, provided the dose of rifabutin is reduced (Abbott Laboratories, Kaletra package insert, 2003 revised). Use of rifabutin with saquinavir alone is not advised given the significant decrease in saquinavir concentration; however, rifabutin may be used with saquinavir if co-administered with ritonavir. Other $\mathrm{PI} /$ ritonavir combinations, including lopinavir/ritonavir, can be safely co-administered with rifabutin as long as the dose of rifabutin is decreased. ${ }^{20}$ Conversely, as a CYP3A4 inducer efavirenz can reduce concentrations of rifabutin, necessitating an increase in the dose of rifabutin. ${ }^{2}$ 
TABLE II. RECOMMENDATIONS FOR CO-ADMINISTERING PROTEASE INHIBITORS AND NON-NUCLEOSIDE REVERSE TRANSCRIPTASE INHIBITORS WITH RIFABUTIN — UNITED STATES, 2004

\begin{tabular}{|c|c|c|c|}
\hline $\begin{array}{l}\text { Single protease } \\
\text { inhibitors }\end{array}$ & $\begin{array}{l}\text { Antiretroviral dose } \\
\text { change }\end{array}$ & $\begin{array}{l}\text { Rifabutin dose } \\
\text { change* }^{*}\end{array}$ & Comments \\
\hline Amprenavir & None & $\begin{array}{l}\downarrow \text { to } 150 \mathrm{mg} / \mathrm{day} \\
\text { or } 300 \mathrm{mg} 3 \times / \text { week }\end{array}$ & $\begin{array}{l}\text { Rifabutin AUC } \uparrow \text { by } 193 \% \text {; no change in } \\
\text { amprenavir concentration. }\end{array}$ \\
\hline fos-amprenavir & None & $\begin{array}{l}\downarrow \text { to } 150 \mathrm{mg} / \text { day } \\
\text { or } 300 \mathrm{mg} 3 x / \text { week }\end{array}$ & Comparable to amprenavir. \\
\hline Atazanavir & None & $\begin{array}{l}\downarrow \text { to } 150 \mathrm{mg} \text { every other day } \\
\text { or } 150 \mathrm{mg} 3 \times \text { week }^{+}\end{array}$ & Rifabutin AUC $\uparrow$ by $250 \%$ \\
\hline Indinavir & $\uparrow$ to $1000 \mathrm{mg} \mathrm{q} 8 \mathrm{~h}$ & $\begin{array}{l}\downarrow \text { to } 150 \mathrm{mg} / \mathrm{day} \\
\text { or } 300 \mathrm{mg} 3 \mathrm{x} / \text { week }\end{array}$ & $\begin{array}{l}\text { Rifabutin AUC } \uparrow \text { by } 204 \% \text {; } \\
\text { indinavir AUC } \downarrow \text { by } 32 \% \text {. }\end{array}$ \\
\hline Nelfinavir & $\uparrow$ to $1000 \mathrm{mg} \mathrm{q} 8 \mathrm{~h}$ & $\begin{array}{l}\downarrow \text { to } 150 \mathrm{mg} / \mathrm{day} \\
\text { or } 300 \mathrm{mg} 3 x / \text { week }\end{array}$ & $\begin{array}{l}\text { Rifabutin AUC } \uparrow \text { by } 207 \% \text {; } \\
\text { nelfinavir AUC } \downarrow \text { by } 32 \%\end{array}$ \\
\hline Ritonavir & None & $\begin{array}{l}\downarrow \text { to } 150 \mathrm{mg} \text { every other day } \\
\text { or } 150 \mathrm{mg} 3 \times / \text { week }\end{array}$ & $\begin{array}{l}\text { Rifabutin AUC } \uparrow \text { by } 430 \% \text {; no change in } \\
\text { ritonavir concentration }\end{array}$ \\
\hline Saquinavir & Rifabutin and saquin & uld not be used together & Saquinavir AUC $\downarrow$ by $43 \%$ \\
\hline $\begin{array}{l}\text { Dual protease inhibitor } \\
\text { combinations }\end{array}$ & $\begin{array}{l}\text { Antiretroviral dose } \\
\text { change }\end{array}$ & $\begin{array}{l}\text { Rifabutin dose } \\
\text { change* }^{*}\end{array}$ & Comments \\
\hline $\begin{array}{l}\text { Lopinavir / ritonavir } \\
\left(\text { Kaletra }^{\mathrm{TM}}\right)\end{array}$ & None & $\begin{array}{l}\downarrow \text { to } 150 \mathrm{mg} \text { every other day } \\
\text { or } 150 \mathrm{mg} 3 \times / \text { week }\end{array}$ & $\begin{array}{l}\text { Rifabutin AUC } \uparrow \text { by } 303 \% \text {; } \\
25-0 \text {-des-acetyl rifabutin } \\
\text { AUC } \uparrow \text { by } 47.5 \text {-fold }\end{array}$ \\
\hline $\begin{array}{l}\text { Ritonavir (any dose) with } \\
\text { saquinavir, indinavir, } \\
\text { amprenavir, fos-amprenavir, } \\
\text { or atazanavir }\end{array}$ & None & $\begin{array}{l}\downarrow \text { to } 150 \mathrm{mg} \text { every other day } \\
\text { or } 150 \mathrm{mg} 3 x / \text { week }\end{array}$ & \\
\hline $\begin{array}{l}\text { Non-nucleoside reverse } \\
\text { transcriptase inhibitors }\end{array}$ & $\begin{array}{l}\text { Antiretroviral dose } \\
\text { change }\end{array}$ & $\begin{array}{l}\text { Rifabutin dose } \\
\text { changet }\end{array}$ & Comments \\
\hline Efavirenz & None & $\begin{array}{l}\uparrow \text { to } 450 \mathrm{mg} / \text { day or } 600 \mathrm{mg} \\
3 x / \text { week }\end{array}$ & $\begin{array}{l}\text { Rifabutin AUC } \downarrow \text { by } 38 \% \\
\text { Effect of efavirenz }+ \text { protease inhibitor (s) } \\
\text { on rifabutin concentration has not been } \\
\text { studied }\end{array}$ \\
\hline Nevirapine & None & $300 \mathrm{mg} /$ day or $300 \mathrm{mg} 3 x /$ week & $\begin{array}{l}\text { Rifabutin and nevirapine AUC not } \\
\text { significantly changed }\end{array}$ \\
\hline Delavirdine & \multicolumn{2}{|c|}{ Rifabutin and delavirdine should not be used together } & $\begin{array}{l}\text { Delavirdine AUC } \downarrow \text { by } 80 \% \text {; } \\
\text { rifabutin AUC } \uparrow \text { by } 100 \%\end{array}$ \\
\hline
\end{tabular}

\section{OTHER DRUG INTERACTION ISSUES}

Further study is needed regarding the co-administration of other complex ARV combinations (e.g. the concurrent use of CYP3A4 inducer and inhibitor, such as efavirenz and a PI) with rifabutin and rifampin (rifampicin). One observational study found that the use of rifabutin with such complex ARV regimens was associated with low serum concentrations of rifabutin, particularly when the rifabutin dose was reduced to $150 \mathrm{mg}$ twice weekly for use with ritonavir-containing regimens. ${ }^{21}$

The NRTIS, which include zidovudine, didanosine, zalcitabine, stavudine, lamivudine, abacavir and emtricitabine, are not metabolised by CYP3A4, so NRTIs and rifampicins may be co-administered without dose adjustments. However, ARV therapy consisting exclusively of NRTIs appears to have reduced potency compared with regimens that contain either a $\mathrm{PI}$ or an NNRTI, and current guidelines recommend NRTI-based regimens only if PIbased or NNRTI-based regimens cannot be used. ${ }^{22}$ As with NRTIs, in vitro and pharmacokinetic data suggest that CYP3A4 is not involved in the metabolism of either the NRTI tenofovir or the fusion inhibitor enfuvirtide, and each is therefore considered safe to use with any of the rifamycins ${ }^{23}$ (and Gilead Sciences Inc., Viread package insert, 2002).

\section{ACQUIRED RIFAMYCIN RESISTANCE}

Rifamycin resistance has developed during the treatment of TB in HIV-infected persons, and has been associated with all rifamycins, particularly with highly intermittent administration (once or twice weekly). Rifapentine, which can be administered once a week, is not recommended for HIV-infected patients because of their risk of developing 
rifamycin resistance..$^{5}$ In addition, rifamycin resistance has developed in patients who have advanced HIV disease (i.e. CD4 count $<100$ cells/Ml) and are receiving rifampin (rifampicin) or rifabutin twice weekly. ${ }^{24-26}$ To prevent acquired rifamycin resistance in persons with advanced HIV infection and $T_{B}$, more frequent therapy (thrice weekly or daily) with either rifampin (rifampicin)- or rifabutin-based TB regimens is recommended.

As new ARV agents and additional pharmacokinetic data become available, recommendations for the use of these agents during the treatment of TB are likely to be revised and updated. More general information on ARV drug interactions can be obtained at http://www.aidsinfo.nih. gov/guidelines and http://www.hiv-druginteractions. org.

Significant contributions to the review of this document were made by the following persons: William Burman, Denver Public Health Department; Philip Spardling, CDC; Paul Weidle, CDC; Jonathan Kaplan, CDC; Alice Pau, NIH; Andrew Vernon, CDC; Harold Jaffe, CDC; M Elsa Villarino, CDC; Richard O'Brien, CDC; Kenneth Castro, CDC; Michael F Lademarco, CDC; Timothy Sterling, Vanderbilt University; Susan Ray, Emory University; Lisa Goozé, University of California, San Francisco; Jean Nachega, Johns Hopkins University; Joseph Burzinski, New York City Department of Health and Mental Hygiene; Sonal Munsiff, New York City Department of Health and Mental Hygiene/ CDC.

\section{REFERENCES}

1. Centers for Disease Control. Prevention and treatment of tuberculosis among patients infected with human immunodeficiency virus: principles of therapy and revised recommendations. MMWR 1998; 47 (no. RR-20).

2. Centers for Disease Conrol. Updated guidelines for the use of rifabutin or rifampin (rifampicin) for the treatment and prevention of tuberculosis among HIV-infected patients taking protease inhibitors or nonnucleoside reverse transcriptase inhibitors. MMWR 2000; 49: 185-189.

3. Burman W, Gallicano K, Peloquin C. Therapeutic implications of drug interaction in the treatment of HIV-related tuberculosis. Clin Infect Dis 1999; 28: 419-430.

4. Li A, Reith $M$, Rasmussen $A$, et al. Primary human hepatocytes as a tool for the evaluation of structure-activity relationship in cytrochrome P450 induction potential of xenobiotics: evaluation of rifampin (rifampicin), rifapentine, rifabutin. Chemico-Biological Interactions 1997; 107: 17-30.

5. Vernon $A$, Burman $W$, Benator $D$, et al. Acquired rifamycin monoresistance in patients with HIV-related tuberculosis treated with once-weekly rifapentine and isoniazid. Lancet 1999; 353: 1843-1847.

6. Kempf D, Marsh K, Kumar G, et al. Pharmacokinetic enhancement of inhibitors of the human immunodeficiency virus protease by co-administration with ritonavir. Antimicrob Agents Chemother 1997; 41: 654-660.

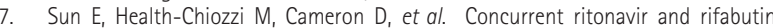
increases risk of rifabutin-associated adverse events. XIth International AIDS Conference, Vancouver, Canada, 1996: abstract MoB171.

8. Moreno S, Podzamczer D, Blazquez $R$, et al. Treatment of tuberculosis in HIVinfected patients: safety and antiretroviral efficacy of concomitant use of ritonavir and rifampin (rifampicin). AIDS 2001; 15: 1185-1187.

9. Lopez-Cortes L, Ruiz-Valderas R, Viciana $P_{1}$ et al. Pharmacokinetic interactions between efavirenz and rifampin (rifampicin) in HIV-infected patients with tuberculosis. Clin Pharmacokinet 2002; 41: 681-690.

10. Patel $A$, Patel $K$, Patel J, et al. To study the safety and antiretroviral efficacy of rifampicin and efavirenz in antiretroviral-naïve tuberculosis co-infected HIV-1 patients in India. Xth Conference on Retroviruses and Opportunistic Infections, Boston, MA, 2003: abstract 438 .

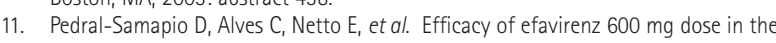
ARV therapy regimen for HIV patients receiving rifampicin in the treatment of tuberculosis. Xth Conference on Retroviruses and Opportunistic Infections, Boston, MA, 2003: abstract 784

12. Veldkamp $A$, Hoetelmans $R$, Beijnen. Ritonavir enables combined therapy with rifampin (rifampicin) and saquinavir. Clin Infect Dis 1999; 29: 1586.

13. la Porte $\mathrm{C}$, Colbers $\mathrm{E}$, Bertz $\mathrm{R}$, et al. Pharmacokinetics of two adjusted dose regimens of lopinavir/ritonavir in combination with rifampin (rifampicin) in healthy volunteers. 42nd Interscience Conference on Antimicrobial Agents and Chemotherapy, San Diego, CA, 2002: abstract A-1823.

14. Robinson $\mathrm{P}$, Lamson $\mathrm{M}$, Gigliotti $\mathrm{M}$, et al. Pharmacokinetic interactions between nevirapine and rifampin (rifampicin). XIlth International AIDS Conference, Geneva, Switzerland, 1998: abstract 60623

15. Dean $G$, Back $D$, de Ruiter $A$, Effect of tuberculosis therapy on nevirapine trough plasma concentration (correspondence). AIDS 1999; 13: 2489-2490.

16. Ribera $E_{1}$ Pou $L$, Lopez RM, et al. Pharmacokinetic interaction between nevirapine and rifampicin in HIV-infected patients with tuberculosis. J Acquir Immune Defic Syndr 2001; 28: 450-453

17. Olivia J, Moreno S, Sanz J, et al. Co-administration of rifampin (rifampicin) and nevirapine in HIV-infected patients with tuberculosis (correspondence). AIDS 2003; 17: 637-642.

18. Cooper C, van Heeswijk, Gallicano K, et al. A review of low-dose ritonavir in protease inhibitor combination therapy. Clin Infect Dis 2003; 36: 1585-1592.

19. Justesen U, Andersen A, Klitgaard N, et al. Pharmacokinetic interaction between rifampin (rifampicin) and the twice-daily combination of indinavir and low-dose ritonavir in HIV-infected patients. Xth Conference on Retroviruses and Opportunistic Infections, Boston, MA, 2003: abstract 542

20. Hollender E, Stambaugh J, Ashkin D, et al. The concomitant use of rifabutin and efavirenz in HIV/TB coinfected patients. Xth Conference on Retroviruses and Opportunistic Infections, Boston, MA, 2003: abstract 785

21. Spradling $\mathrm{P}$, Drociuk $D$, McLaughlin $\mathrm{S}$, et al. Drug-drug interactions in inmates treated for human immunodeficiency virus and Mycobacterium tuberculosis infection or disease: an institutional tuberculosis outbreak. Clin Infect Dis 2002 35: 1106-1112.

22. US Department of Health and Human Services, Guidelines for the Use of Antiretroviral Agents in HIV-1-Infected Adults and Adolescents. November 10, 2003. http://aidsinfo.nih.gov

23. Boyd $M$, Ruxrungtham $K$, Zhang $X$, et al. Enfuvirtide: investigations on the drug interaction potential in HIV-Infected patients. Xth Conference on Retroviruses and Opportunistic Infections, Boston, MA, 2003: abstract 541.

24. El-Sadr W, Perlman D, Matts J, et al. Evaluation of an intensive intermittentinduction regimen and duration of short-course treatment for human immunodeficiency virus-related pulmonary tuberculosis. Clin Infect Dis 1998; 26 1148-1158.

25. CDC Acquired rifamycin resistance in persons with advanced HIV disease being treated for active tuberculosis with intermittent rifamycin-based regimens. MMWR 2002; $51: 214-215$

26. Nettles R, Mazo D, Alwood K, et al. Tuberculosis relapse and acquired rifamycin resistance in HIV-1 infected persons is associated with low CD 4 count but is not more common with rifabutin than rifampin (rifampicin). Xth Conference on Retroviruses and Opportunistic Infections, Boston, MA, 2003: abstract 137.

This document (updated 20 January 2004) is on the CDC Division of Tuberculosis Elimination website at www.cdc.gov/nchstp/tb/TB_HIV_Drugs/TOC.htm 